\title{
Demystifying the Crime of Aggression: A Case for the International Criminal Court
}

\author{
Edrine Wanyama*
}

\begin{abstract}
The crime of aggression forms one of the most controversial parts of international law in contrast with the need to protect national sovereignty of a given state without undue interference. Even with the adoption of the Rome Statute in 1998, the crime of aggression seems to have been sidelined in favour of other matters of international justice concerns that did not directly touch the political status of the different states parties. Jurisdictional issues concerning aggression were left unresolved. The term 'aggression' was nevertheless given recognition in the year 2010 at a Review Conference of the Rome Statute held in Kampala, Uganda, from 31 May to 11 June 2010. However, the concept still remains on paper due to the postponement in establishing the jurisdiction of the International Criminal Court till 2017. Currently, only four states have signed and ratified the amendments to the Rome Statute 1998 and they are to be enforced over the next couple of years. This article gives an overview of the crime of aggression. It examines some of the contentious issues that may arise in relation to the crime of aggression.
\end{abstract}

Keywords: Aggression; International Criminal Court; Review Conference; Rome Statute; United Nations

* Uganda Human Rights Network, Kampala, Uganda; edrinewanyama@gmail.com 


\section{Introduction}

In 1998, at the Rome Conference that adopted the Rome Statute of the International Criminal Court (hereinafter referred to as "ICC"), the crime of aggression was included as one of the crimes within its jurisdiction. ${ }^{1}$ To this end, any state that becomes party to the Statute accepts the ICC's jurisdiction. ${ }^{2}$ However, neither was there a unanimous agreement between the participants to the Rome Conference as to the agreed definition of the crime of aggression, nor was there a reached agreement on further conditions for the ICC's exercise of jurisdiction.

It was therefore clear that under the Statute, the ICC could not exercise such jurisdiction until these outstanding issues were solved. ${ }^{3}$ This does not, however, conclude that no jurisdiction is conferred upon the ICC and neither does it mean that further steps can be taken for the actualization of a definition for the crime of aggression. In this commitment therefore, subsequent Preparatory Commission for the ICC led to proposals for a provision on aggression in the form of a 2002 Coordinator's Discussion Paper, which was updated in early 2007.4

\section{The Crime of Aggression}

In September 2002, the Assembly of States Parties to the ICC established a Special Working Group on the Crime of Aggression (hereinafter referred to as "SWGCA") to continue discussions on the crime of aggression, and this was open to all states including non state parties. The SWGCA has met both formally and informally

\footnotetext{
${ }^{1}$ Rome Statute of the International Criminal Court art. 5.1, July 1, 2002, 2187 U.N.T.S. 90.

2 Rome Statute of the International Criminal Court art. 12.1, supra note 1.

${ }^{3}$ Rome Statute of the International Criminal Court art. 5.2, supra note 1.

${ }^{4}$ Coalition for the International Criminal Court, The ICC and the Crime of Aggression (May 1, 2007), available at http://www.iccnow.org/ documents/CICCFS_Crime_of_Aggression_Factsheet_FINAL_eng_1May 07.pdf (last visited Oct. 16, 2012).
} 
from 2003 through 2007. 5 In the year 2010, a Review Conference of the Rome Statute was held in Kampala, Uganda, from 31st May to 11th June and thereupon, amendments were adapted to the crime of aggression on 11th June that year by Resolution RC/Res. 6. The amendments were circulated under the cover of depositary notification C.N.651.2010.TREATIES-8 of 29 November $2010 .^{6}$

It was also agreed that certain conditions be put in place in order to have the crime of aggression come into full play. In other words, the crime would be recognized but would be prosecuted at a given specific time. In this regard, the condition for entry into force decided upon in Kampala provides that the court will not be able to exercise its jurisdiction over the crime until after 1st January, 2017 when a decision is to be made by states parties to activate the jurisdiction. ${ }^{7}$

This definitely presents a process of realization of goals sought for by the different state parties. It is as such a progressive realization, and the most significant hurdle in the course of understanding, defining and penalising aggression is that the individual opinion of each state regarding aggression varies with the circumstances related to them. Despite this, the crime presents legal and social aspects that must be looked into. It requires continued understanding and simplification of its true nature. This article attempts to fill the existing vacuum and provide a simplification of the crime of aggression to the reader.

The crime of aggression is defined as the planning, preparation, initiation or execution by a person in a leadership position of an act

${ }^{5}$ Coalition for the International Criminal Court, The ICC and the Crime of Aggression (Jan., 2008), available at http://www.iccnow.org/ documents/ CICCFS_Crime_of_Aggression_Factsheet_eng_ASP_6_Jan08.pdf (last visited Oct. 16, 2012).

6 See Review Conference of the Rome Statute, Res. RC/Res.6 (Jun. 11, 2010), available at http://treaties.un.org/Pages/ViewDetails.aspx?src =TREATY\&mtdsg_no=XVIII-10-b\&chapter=18\&lang=en.

7 Coalition of International Criminal Court, Delivering on the promise of a fair, effective and independent Court: The Crime of Aggression, available at http:/ / www.iccnow.org/?mod=aggression (last visited Oct. 16, 2012). 
of aggression. 8 Most importantly, the definition contains the threshold requirement that the act of aggression must constitute a manifest violation of the Charter of the United Nations. ${ }^{9}$ Notably, this definition was universally adopted and required the strict following of the core guiding principles for the consideration of the crime of aggression at the review conference. This included principles such as independence of the ICC, integrity of the Rome Statute, preservation of the legitimacy of the ICC, fair trial and due process and the complementary role of the ICC. ${ }^{10}$ Despite the above, the definition of the crime of aggression is not without criticism and it has been observed that the definition is derived from political origins. ${ }^{11}$ Assessment of political policy and addressing the issues of state responsibility was permitted by the United Nations General Assembly vide its resolution 3314 (XXIX) of December 14th, 1974. Scholars are therefore of the view that, "necessity to take into account political motivations moves the definition away from that which is legally recognizable." 12 They further argue that the definition did not foresee the application to individual liability, ${ }^{13}$ thereby leading to legal uncertainty which

8 Rome Statute of the International Criminal Court art. 8bis, supra note 1.

9 See generally The Charter of United Nations, 24 Oct. 1945, 1 U.N.T.S. XVI, available at http://treaties.un.org/doc/Publication/CTC/uncharter.pdf (last visited Oct. 16, 2012).

10 See Coalition for the International Criminal Court, Guiding Principles for the Consideration of the Crime of Aggression at the Review Conference of the Rome Statute of the International Criminal Court (2010), available at http://www.iccnow.org/documents/RC_Report_finalweb.pdf.

11 Noah Weisbord, Prosecuting Aggression, 49(1) HARV. INT'L L.J. 161, 169 (2008); Sergey Sayapin, A Great Unknown: The Definition of Aggression Revisited, 17 MicH.ST. J. INT'L L. 377 (2008-2009); Oscar Solera, The Definition of Aggression: Lessons Not Learned, 42 CASE W. RES. J. INT'L L. 801, 812 (2009-2010).

12 Cale Davis, Susan Forder, Tegan Little, Dali Cvek, The Crime of Aggression and the International Criminal Court, 17(1) THE NATIONAL LEGAL EAGLE (2011).

13 Grant Dawson, Defining Substantive Crimes Within the Subject Matter Jurisdiction of the International Criminal Court: What is the Crime of Aggression?, 19 N.Y.L. SCH. J. INT.'L \& COMP. L. 413 (1999-2000); Devyani 
becomes rather inappropriate for an independent and impartial court. ${ }^{14}$

Hope at this level is, however, not lost. A general understanding of the resolution 3314 does not comprehensively depict what they think it should have covered. The resolution was not intended to be used in a judicial setting, though it does phrase its determinative criteria in legal language. ${ }^{15}$ Even with this, the independence of the court in the process of handling all crimes listed under the Rome Statute needs further review and more care has to be taken when it comes to dealing with the crime of aggression. The act of aggression is defined under paragraph 2 of Article 8bis of the Rome Statute, 2002 as meaning the use of armed force by a state against the sovereignty, territorial integrity or political independence of another state, or in any other manner inconsistent with the Charter of the United Nations. The provision is further elaborative and lists acts that qualify as acts of aggression. For purposes of actual impression and self analysis, paragraph 2 specifically provides that:

Any of the following acts, regardless of a declaration of war, shall, in accordance with United Nations General Assembly resolution 3314 (XXIX) of 14 December 1974, qualify as an act of aggression:

a) The invasion or attack by the armed forces of a State of the territory of another State, or any military occupation,

Kacker, Coming Full Circle: The Rome Statute and the Crime of Aggression, 33 SufF. TRANS. L. REV. 257 (2010); Michael Glennon, The Blank-Prose Crime of Aggression, YALE J. INT.'L L. 71 (2010) (note one of the most important issues which divide State responsibility from criminal responsibility with respect to the crime of aggression is arguably the mental element i.e. mens rea, which Resolution 3314 does not include); see Solera, supra note 11 at 811, 815-9; Kari Fletcher, Defining the Crime of Aggression: Is There an Answer to the International Criminal Court's Dilemma?, 65 A.F.L. REV. 229, 253 (2010).

14 See Solera, supra note 11 at 806 (for relevant discussions of the nullum crimen, nulla peona, sine previa lege penale concept); see also Fletcher, supra note 13 at 254 .

15 David Rupiny, ICC States Strike Deal on Aggression, 108 INT.'L JUST. TRI 1 (2010). 
however temporary, resulting from such invasion or attack, or any annexation by the use of force of the territory of another State or part thereof;

b) Bombardment by the armed forces of a State against the territory of another State or the use of any weapons by a State against the territory of another State;

c) The blockade of the ports or coasts of a State by the armed forces of another State;

d) An attack by the armed forces of a State on the land, sea or air forces, or marine and air fleets of another State;

e) The use of armed forces of one State which are within the territory of another State with the agreement of the receiving State, in contravention of the conditions provided for in the agreement or any extension of their presence in such territory beyond the termination of the agreement;

f) The action of a State in allowing its territory, which it has placed at the disposal of another State, to be used by that other State for perpetrating an act of aggression against a third State;

g) The sending by or on behalf of a State of armed bands, groups, irregulars or mercenaries, which carry out acts of armed force against another State of such gravity as to amount to the acts listed above, or its substantial involvement therein. ${ }^{16}$

The definition gives a deeper understanding of the crime of aggression. But this does not rule out the possibility of ambiguities. With regard to the criticisms noted earlier, the implication is that there is an ever growing need to have a simpler definition with elaborate explanations. But as of now, the ball still lies with the ICC to carry out the duty of explaining what the true meaning of the crime of aggression is. The reader has to wait for a more user friendly definition and explanation of aggression as a crime.

\footnotetext{
${ }^{16}$ Rome Statute of the International Criminal Court art. 8 bis, supra note 1.
} 
It is vital to note that one of the main reasons that delayed the acceptance of the crime of aggression under the Rome Statute in 1998 was the problem of determination of jurisdiction over the crime. Hence, arises the need to consider the jurisdictional and enforceability issues pertaining to aggression.

\section{Conditions for Exercise of Jurisdiction over the Crime of Aggression}

The conditions for exercise of jurisdiction are listed in articles 15bis for state referrals and 15ter for Security Council referrals. It is upon satisfaction of the conditions in the above Articles that the ICC may exercise jurisdiction over the crime of aggression. Save for the other crimes in the Statute, these Articles establish a unique jurisdictional regime outlining when the ICC Prosecutor can initiate an investigation into a crime of aggression.

Where a 'situation' is referred to the prosecutor by the UN Security Council, Article 15ter of the statute provides that the court's jurisdiction is triggered in the same manner as with the other crimes in the statute, meaning the prosecutor may proceed with an investigation into the crime of aggression on the same trigger mechanism. Specifically, jurisdiction will be exercised where the crime of aggression is committed in accordance with Article 13 (b), subject to the provisions of Article 15ter, committed one year after the ratification or acceptance of the amendments by thirty states parties. This is subject to a decision to be taken after 1st January, 2017 by the same majority of states parties as is required for the adoption of an amendment to the statute. A determination of an act of aggression by an organ outside the court shall be without prejudice to the court's own findings under this statute.

Further, this particular article is without prejudice to the provisions relating to the exercise of jurisdiction with respect to other crimes referred to in Article 5. The principle of safeguarding against double jeopardy is to be followed.

In contrast to Security Council referrals, under Article 15bis, the statute provides for referral by the state and the prosecutor. In light of this, the prosecutor may only proceed with propio motu or own motion investigation, or an investigation based on a state referral of 
a situation into the crime of aggression. The conditions under this Article are:

1. That the exercise of jurisdiction must be in accordance with Article 13, paragraphs (a) and (c), subject to the provisions of this Article,

2. The crime must have been committed one year after the ratification or acceptance of the amendments by thirty states parties,

3. The decision to exercise jurisdiction over the offence must be subject to a decision to be taken after 1 January, 2017 by the same majority of state parties as is required for the adoption of an amendment to the statute,

4. The court may exercise jurisdiction in accordance with Article 12 where the crime of aggression is arising from an act of aggression committed by a state party, unless that state party has previously declared that it does not accept such jurisdiction by lodging a declaration with the Registrar of ICC,

5. The withdrawal of such a declaration may be affected at any time and shall be considered by the state party within three years,

6. The court shall not exercise jurisdiction over the states that are not party to the statute,

7. Where the prosecutor reasonably believes that there is need to proceed with investigation of such crime, he or she shall first ascertain the determination by the Security Council and where such determination has been made within six months, then the prosecutor shall proceed with the investigation,

8. A determination of an act of aggression by an organ outside the court shall be without prejudice to the court's own findings under this statute,

9. This particular Article is without prejudice applicable to the provisions relating to the exercise of jurisdiction with respect to other crimes referred to in Article 5. 


\section{Enforceability and Jurisdiction}

Following the amendments reached in consensus and in accordance with Article 5(2) of the statute and the agreement that the states parties would enter into force under Article 121(5), the amendments would enter into force for a state one year after such a state has ratified or accepted them. ${ }^{17}$ A state that intends not to be bound by the amendment would therefore as a must make a declaration to that effect and a state that does nothing to that effect is bound by the amendment. This means that it is a process that will require states to ratify or accept to be bound by the amendments. However, as earlier noted, under Article 15bis, non state members are exempted from the court's jurisdiction. The court will only start exercising jurisdiction when at least thirty states have ratified the amendment. ${ }^{18}$ Even with thirty states, the court has to wait until January, 2017 in order for it to commence its work in this respect and moreover with a two thirds support. This has however been criticized for reasons that though with the intention to attract or encourage more states to sign, ratify or accede to the statute, the period of seven years is too long and creates a lot of laxity for members to join and become parties. It is more or less a hindrance. With this, however, every effort must be recognized as it shows that there is a progressive move in the bid to achieve international justice and further seeking for an end to impunity.

The general aspect as to when jurisdiction of the court becomes active is that by virtue of Article 15 paragraph 5, the amendments come into force for each state ratifying individually at that point of ratification. "In addition, the amendments require two further conditions to be fulfilled for the court to exercise jurisdiction, both for state referrals and proprio motu investigations and for Security Council referrals:

\footnotetext{
17 Rome Statute of the International Criminal Court art. 121(5), supra note 1.

18 Rome Statute of the International Criminal Court art. 15 bis(2), supra note 1 .
} 
i. The court may exercise jurisdiction only with respect to crimes of aggression committed one year after the ratification or acceptance of the amendments by thirty states parties.

ii. The court shall exercise jurisdiction over the crime of aggression in accordance with this Article, subject to a decision to be taken after 1 January, 2017 by the same majority of states parties as is required for the adoption of an amendment to the Statute" ${ }^{\prime 19}$

It ought to be noted that most of the states parties do not have a positivist approach for the work of the court. For instance, the Coalition for the International Criminal Court (hereinafter referred to as "CICC") represents over 2,500 organizations that strongly support the Rome Statute system from all over the world with differing mandates and expertise. The CICC as a whole does not take a position concerning the adoption of specific provisions on the crime of aggression at Kampala. This was because CICC members developed varying positions concerning the complex discussions on the crime. Likewise, the Uganda Coalition on the International Criminal Court (hereinafter referred to as "UCICC") takes a similar position. Nevertheless, both before and during the Review Conference, the CICC and the UCICC encouraged states to approach the consideration of proposals concerning the crime of aggression on their merits and in a constructive and cooperative manner. The CICC team on the crime of aggression was actively involved in the 'Princeton process' 20 and in the preparatory work undertaken by the SWGCA. During the Review Conference, the CICC and the UCICC were active in providing information and forums for discussion on the topic to its membership and states delegates.

Despite the above, it is with international interest that the crime of aggression be taken more seriously. It is unanimously agreed and recognized that aggression is the most serious and dangerous form

19 Rome Statute for the International Criminal Court art. 15 bis, 15 ter, supra note 1 .

${ }^{20}$ Coalition of International Criminal Court, supra note 7. 
of the illegal use of force. The determination of whether an act of aggression has been committed requires consideration of all the circumstances of each particular case, including the gravity of the acts concerned and their consequences, in accordance with the Charter of the United Nations. As such, it has been understood by all states that attended the Kampala Conference that in establishing whether an act of aggression constitutes a manifest violation of the Charter of the United Nations, the three components of character, gravity and scale must be sufficient to justify a 'manifest' determination. No one component can be significant enough to satisfy the manifest standard by itself. ${ }^{21}$

\section{Conclusion and Recommendations}

The ICC is young and still very fragile for those dependent on international support.22 If the state parties do not accept the jurisdiction of the ICC on the crime of aggression by reason of lack of independence or any other concerns, this will imply reduced support for the ICC and would undermine the efforts for international justice. State parties may have attempted to overcome these concerns to reach a definition of the crime of aggression that alleviates these weaknesses as much as possible. However, the special jurisdictional requirements adopted at Kampala compared with other crimes under the Rome Statute, 2002 demonstrates the 'fundamental unwillingness' of states to accept too much judicial intervention and may be perceived as lack of support. ${ }^{23}$

21 See Review Conference of the Rome Statute, supra note 6 at 17.

22 (all international courts and organizations rely on the support of State parties, which makes international courts fundamentally less independent than domestic courts since international courts cannot afford to isolate themselves in a political vacuum); see also Robert Schaeffer, The Audacity of Compromise: The UN Security Council and the Pre-conditions to the Exercise of Jurisdiction by the ICC with Regard to the Crime of Aggression, 9 INT'L C.L.R. 411, 420 (2009).

23 Dov Jacobs, The Sheep in the Box: The Definition of the Crime of Aggression at the International Criminal Court, in THE REVIEW CONFERENCE \& THE Future OF The Icc Proceedings OF The First AidP SyMposium For 
$\mathrm{RC} /$ Res.6 undermines the fundamental purposes of the ICC. The jurisdictional regime's reliance upon the Security Council erodes the independence of the prosecutor and the judiciary and consequently leads to impunity. Allowing states to arbitrarily determine whether the ICC can exercise jurisdiction for the crime of aggression in relation to their nationals results in continued impunity and a failure to reaffirm the Charter of the UN. Deriving the definition of an act of aggression from Res. 3314 subjects all determinations of criminal liability to political motivations, reducing judicial independence. In addition, the incorporation of the manifest threshold RC/Res.6 does not reaffirm the Charter, but restricts its application. While there is no such thing as a magical formula to which all parties will agree without compromise it is important to recognize the potential shortcomings of RC/ Res.6 that may weaken the court. ${ }^{24}$

Most importantly, it must be known that there is no positive step toward a goal that is not met with challenges. It is not with doubt that criticisms have come up against the ICC, its work and as well as its progress. However, the platforms for debate, works and related activities of the ICC must be utilised in such a way that there is effective participation and contribution to the eventual success of the court and perceive it as an instrument of change.

Young PENALISTS 131-151 (Christoph Burchard, Otto Triffterer \& Joachim Vogel eds., Kluwer Law International 2010).

${ }^{24}$ Cale, supra note 12; Solera, supra note 11 at 812. 